\title{
Cigarette Ignition of Soft Furnishings
}

\author{
RICHARD G. GANN, RICHARD H. HARRIS, JR., JOHN F. KRASNY, \\ ROBERT S. LEVINE, HENRI E. MITLER, and THOMAS J. OHLEMILLER \\ Center for Fire Research \\ National Bureau of Standards \\ Gaithersburg, Maryland 20899, USA
}

\begin{abstract}
Changes in the propensity of cigarettes to ignite upholstered furniture and bedding could reduce fire losses significantly. This paper describes fundamental and empirical studies of the effect on ignition propensity of varying cigarette characteristics. Reduced tobacco density, circumference and paper porosity were especially effective. Energy transfer from the cigarette to the substrate was measured and relationships between cigarette combustion behavior and ignition propensity were explored. Using these data, computer modeling of the cigarette on a substrate manifested key features of the ignition process. A fully-documented technical report is available. [1]
\end{abstract}

\section{INTRODUCTION}

Cigarette ignition of upholstered furniture and mattresses is by far the single leading cause of fire deaths in the United States. For the $600 \mathrm{~B}$ cigarettes sold annually [2], the probability of one being dropped, igniting soft furnishings and leading to a death or injury is smal1. Yet in $1984,49,000$ cigarette-initiated fires resulted in 1,530 deaths, 7,000 serious injuries, and $\$ 320 \mathrm{million}$ of destroyed property. [3]

Extensive efforts have been devoted to reducing the susceptibility to cigarette ignition of both upholstered furniture and mattresses. A mandatory standard for mattresses [4] and voluntary standards for upholstered furniture $[5,6]$ have led to manufacture of less readilyignited soft furnishings. Yet, even these highly-productive efforts are not enough to end the losses from cigarette-initiated fires quickly. These commodities have average Iifetimes of about fifteen years [7], so the full impact of the improved furniture on fire safety will not be realized for decades to come. By contrast, cigarettes are consumed within a few months of their production, leading to the possibility that fire losses could be reduced sooner if the cigarette were suitably modified.

This paper describes a major project to measure and model the impact of changes in cigarette traits on the ignition of upholstered furniture and mattresses. The work was performed under the Cigarette Safety Act of 1984 as part of a program to determine the technical and commercial. feasibility, as well as the economic impact, of developing less ignitionprone cigarettes. Reports on the complete program are avallabie. 
Cigarette ignition of furniture occurs when the burning cigarette heats the furniture fabric or padding to the point where it begins to smolder (Figure 1) Therefore, a less ignition-prone cigarette must generate le heat (i.e., burn less fuel), restrict access of oxygen to the fuel, or heat the fabric less efficiently.

A cigarette is a cylinder (column) of tobacco strips wrapped in paper, usually with a filter tip at one end. A cigarette can be described by the type of tobacco, the density of that tobacco in the colum, the length and circumference of that column, the thickness and porosity of the wrapping paper, and any additives to either the tobacco or the pape The tobacco density may be decreased by expanding the volume of the tobacco strands and by cutting them wider. Citrates are conventionally added to the paper to produce an even, clean-appearing burning. This description suggests a number of cigarette characteristics for variatio

\section{APPROACH}

The work reported here ranges from basic research into the physics of $t$ ignition process to highly empirical studies of the manifest cigarette features affecting ignition.

An inexpensive, rapid procedure was adopted for evaluating a variety of test cigarettes on a range of substrates. ${ }^{1}$ The bench-scale mockups of furniture (Figure 2) that were used also provided a link to the bulk of previous testing of this ignition process. [8,9] To assess the validit of the mockup tests, some experiments were run using mockups and chairs made of the same materials.

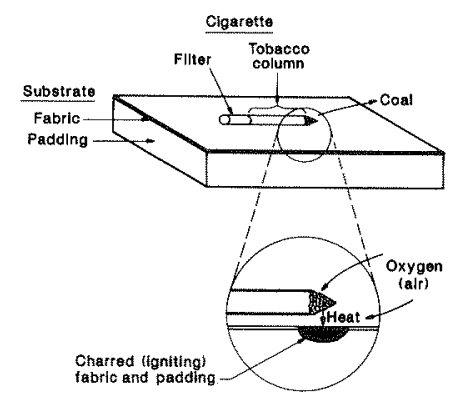

Figure 1. Cigarette Ignition of Upholstered Furniture.

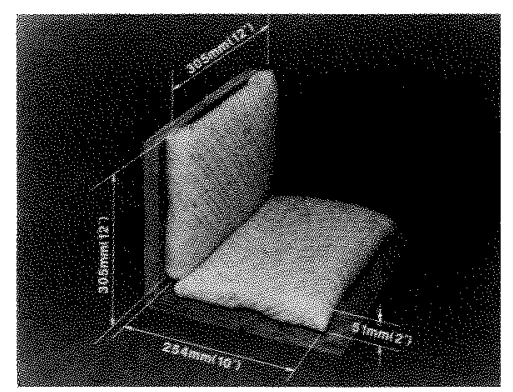

Figure 2. Furniture Mock for Ignition Testing.

1The term "substrate" is used to characterize a piece of upholster. furniture, a mattress, or a laboratory mockup of one of these. It mean, one combination of a specific fabric and padding, in either a flat or crevice configuration, with or without a cover sheet. (The cover sheet simulates, e.g., a sheet pulled over the real-life cropped cigarette.) For example, one substrate would be the flat area of a piece of polyurethane foam covered with an olefin fabric, with the cigarette covered by sheeting. The flat area with the same materials, but with t cigarette not covered would be a different substrate. 
Twelve commercial cigarette types were chosen that fit the following criteria: (1) high, low, or middle expected ignition propensity; and/or (2) large market share. The cigarettes were supplied by their manufacturers without brand identification and were designated numbers 1 12. With much difficulty, substrates were found that would differentiate among the ignition propensities of these twelve cigarettes, indicating that the differences in ignition propensity among these commercial cigarettes were small. [10]

Forty-one types of experimental cigarettes were specially prepared for this study by the cigarette industry. They varied in tobacco type and density, paper permeability and citrate content, and circumference. The wrappers and fillers were selected for systematic and broad property variation, not necessarily indicative of current commercial cigarettes. Detailed descriptions of the cigarettes' physical and combustion properties were provided or obtained.

Table 1. Description of Experimental Cigarettes

\begin{tabular}{|c|c|c|c|c|c|c|}
\hline No. & Iobacco & $\begin{array}{l}\text { Tobacco } \\
\text { Density }\end{array}$ & $\begin{array}{cc}\text { Paper } \\
\text { Porosity }\end{array}$ & $\begin{array}{c}\text { Citrate } \\
\text { Added }\end{array}$ & $\begin{array}{c}\text { Circum- } \\
\text { ference } \\
\text { (mm) }\end{array}$ & $\begin{array}{l}\text { Second } \\
\text { Paper } \\
\text { Wrapping }\end{array}$ \\
\hline 101 & Burley & High & Low & Yes & 21 & No \\
\hline 102 & Burley & $\mathrm{High}$ & Low & No & 21 & No \\
\hline 103 & Burley & Aigh & $\mathrm{H}+\mathrm{gh}$ & Yes & 21 & No \\
\hline 204 & Burley & $\mathrm{High}$ & $\mathrm{High}$ & No & 21 & No \\
\hline 105 & Burley & Low & Low & Yes & 21 & No \\
\hline 106 & Burley & Low & Low & No & 21 & No \\
\hline 107 & Burley & Low & $\mathrm{High}$ & Yes & 21 & No \\
\hline 108 & Burley & Low & $\mathrm{High}$ & No & 21 & No \\
\hline 109 & Flue-Cured & $\mathrm{High}$ & Low & Yes & 21 & No \\
\hline 110 & Elue-Cured & $\mathrm{High}$ & Low & No & 21 & No \\
\hline 111 & Flue-Cured & Hith & High & Yes & 21 & No \\
\hline 112 & Flue-Cured & High & $\mathrm{High}$ & No & 21 & No \\
\hline 113 & Flue-Cured & Low & Low & Yes & 21 & No \\
\hline 114 & Flue-Cured & Low & Low & No & 21 & No \\
\hline 115 & Flue-Cured & Low & High & Yes & 21 & No \\
\hline 116 & Flue-Cured & Low & $\mathrm{High}$ & No & 21 & No \\
\hline 117 & Burley & High & Low & Yes & 25 & No \\
\hline 118 & Burley & $\mathrm{High}$ & Low & No & 25 & No \\
\hline 119 & Burley & High & $\mathrm{High}$ & Yes & 25 & No \\
\hline 120 & Burley & High & High & No & 25 & No \\
\hline 121 & Buriey & Low & Low & Yes & 25 & No \\
\hline 122 & Burley & Low & Low & No & 25 & No \\
\hline 123 & Burley & Low & $\mathrm{H \perp gh}$ & Yes & 25 & No \\
\hline 124 & Burley & Low & High & No & 25 & No \\
\hline 125 & Flue-Cured & High & Low & Yes & 25 & No \\
\hline 126 & Flue-Cured & HIgh & Low & No & 25 & No \\
\hline 127 & Flue-Cured & High & $\mathrm{HLgh}$ & Yes & 25 & No \\
\hline 128 & Flue-Cured & $\mathrm{High}$ & High & No & 25 & No \\
\hline 129 & Elue-Cured & Low & Low & Yes & 25 & No \\
\hline 130 & Flue-Cured & Low & Low & No & 25 & No \\
\hline 131 & Flue-Cured & Low & High & $Y \in s$ & 25 & No \\
\hline 132 & Flue-Cured & Low & High & No & 25 & No \\
\hline 201 & Flue-cured & Low & Very Low & No & 21 & No \\
\hline 202 & Flue-cured & Low & Very Low & No & 25 & No \\
\hline 203 & Flue-cured & Low & Very Lowa & No & 25 & No \\
\hline 204 & Flue-cured & Low & Very Low ${ }^{b}$ & No & 25 & No \\
\hline 205 & Flue-cured & Low & Very Low $a, b$ & No & 25 & No \\
\hline 206 & Flue-Cured & Low & Very Low & No & 25 & Yes \\
\hline 207 & Flue-cured & Low & Very Low & No & 25 & Yes \\
\hline 208 & Flue-cured & Low & Very Low & No & 25 & Yes \\
\hline 209 & Flue-Cured & Low & Very Low ${ }^{a, b}$ & ${ }^{b}$ No & 25 & Yes \\
\hline
\end{tabular}


To test these experimental cigarettes, fabrics and padding materials wer selected to represent furniture having a range of susceptibility to cigarette ignition. These included some of the most ignition-prone materials available.

Table 2. Materials Used in Ignition Measurement

\section{Fabrics}

California Standard cotton velvet

Blue Denim, cotton

"Splendor," plain weave cotton

"Haitian" (heavy, raw) cotton

Heavy velvet

Cotton duck

Damask

Olefin, backcoated

\section{Paddings}

Gotton batting (untreated Polyurethane foam

Five embodiments of cigarette patents were received from their inventor: Each was accompanied by "controls," i.e., supposedly identical cigarettes, but without the patented feature. The five patented design features, as provided by the patent holders, were:

\footnotetext{
- Very low porosity, high weight paper with a high citrate leve then electrostatically perforated to a high porosity;

- Sodium silicate added to $5 \mathrm{~mm}$ in the center of the tobacco ro

- Two $6.5 \mathrm{~mm}$ bands, $15 \mathrm{~mm}$ apart, of low porosity paper attached at fixed intervals to the inside surface of the cigarette wrapper, which has a medium porosity and 0.88 sodium potassiu citrate;

- Application to the exterior paper surface of a water suspensi containing non-fat dry milk and mono-ammonium phosphate; and

- Addition to the tobacco column of an intumescent silicate.
}

The compositions of the patented cigarettes and their controls were not verified. All these cigarettes and their controls were tested in the same manner as the cigarettes above, including some more ignition-prone substrates.

In all tests, the ignition criterion used was a clear appearance of ignition, confirmed by a significant weight loss of the

cigarette/substrate assembly. The testing included both flat and crevi. configurations. At least five replicate tests were performed for each cigarette/substrate combination. The data were statistically analyzed for correlations between numbers of ignitions and the individual cigarette characteristics.

Similar testing was performed on chairs manufactured of some of the sam materials, and the data analyzed to determine the extent to which these full-scale results were predicted by the bench-scale tests. In additio samples of some of the materials and cigarettes used were sent to the California Bureau of Home Furnishings for testing to determine interlaboratory reproducibility of these results. [11] Moderate and easy-to-ignite substrates were used.

The ignition process depends on the energy transfer from cigarettes to furniture items. This was studied using fine thermocouples and a heat 
flux gauge to follow the temperature and energy flux histories while cigarettes smoldered on different substrates. Two-dimensional infrared imaging radiometry was used to map the thermal response of the substrate. Graphical correlations were explored between measured properties of the burning cigarettes and their measured ignition propensities.

Both fundamental and semi-empirical mathematical modeling of the lit cigarette and ignition of the substrate were pursued. Each borrowed heavily from prior efforts elsewhere. A comprehensive list of the involved materials properties and physical processes was compiled. Substantial simplifications were made in representing these. The predictions from the resulting FoRTRAN programs were tested, to a limited extent, against the trends observed in the laboratory tests.

Finally, the experience and knowledge gained from the above research were applied to the task of developing a convenient, accurate test method for cigarette ignition propensity. Several previously-suggested and new approaches were analyzed and tested in the laboratory, but the development of a viable test method has not yet been completed.

\section{RESULTS}

The principal findings of this research are as follows.

1. In furniture mock-up tests involving a wide range of fabrics and paddings, the best of the experimental cigarettes tested had considerably lower ignition propensities than commercial cigarettes.

\section{Table 3. Ignition Propensities of Selected Test Cigarettes}

Experimental

Designation

$\frac{\text { No. Ignitions }}{20 \text { Tests }}$

Cigarettes

$\begin{array}{rrr}201 & 0 & 0 \\ 106 & 1 & 5 \\ 202 & 2 & 10 \\ 130 & 4 & 20 \\ 114 & 4 & 20 \\ 105 & 6 & 30 \\ 113 & 6 & 30 \\ 108 & 7 & 35 \\ 122 & 7 & 35 \\ 129 & 10 & 50 \\ 107 & 11 & 55 \\ 120 & 20 & 100 \\ 127 & 20 & 100\end{array}$

Least Ignition-Prone

Commercial Cigarettes

Typical Ignition

Propensity Commercial

Cigarettes 
2. Three cigarette characteristics were found to reduce ignition propensity significantly: low tobacco density, reduced circumference, and low paper permeability. Considerably larger reductions were achiev with combinations of these. The tobacco column length, the presence of filter tip, and citrate content of the paper had effects in limited cases. The tobacco blend had minimal impact on ignition propensity.

\section{Table 4. Ignition Propensity as a Function of Experimental Cigarette Characteristics}

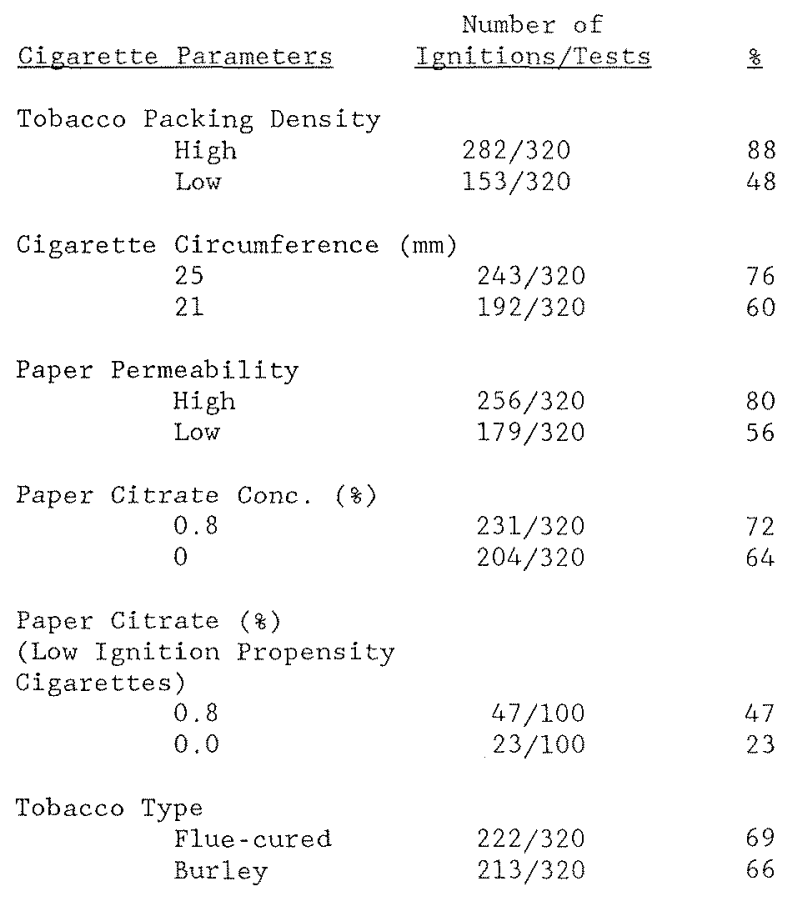

Non-ignitions were often achieved without the cigarettes self-

extinguishing during the test; i.e., many cigarettes burned their full length without igniting the substrate.

3. Some of the best-performing experimental cigarettes had average per puff tar, nicotine, and Co yields comparable to or only slightly greate than typical comnercial cigarettes. Possible differences in the composition or toxicology of the smoke delivered by these cigarettes we not investigated.

4. Each of five patented cigarette modifications also showed reduced ignition propensity over their submitted controls and the typical curre commercial cigarettes. 
5. The interlaboratory repeatability of the mock-up measurements was excellent.

Table 5. Interlaboratory Comparison of the Number of Ignitions for Various Cigarettes and Substrates (flat surface/uncovered cigarettes; 5 tests each)

\begin{tabular}{|c|c|c|c|c|}
\hline \multirow{3}{*}{$\begin{array}{l}\text { Cigarette } \\
\text { Number }\end{array}$} & \multicolumn{2}{|c|}{ Gotton Batting } & \multicolumn{2}{|c|}{ Polyurethane Fc } \\
\hline & Califor & a Fabric & Splendor & Fabr \\
\hline & CFR & $\underline{B H F}$ & $\underline{\mathrm{CFR}}$ & $\mathrm{BHF}$ \\
\hline 3 & 5 & 5 & 5 & 5 \\
\hline 102 & 2 & 1 & 5 & 5 \\
\hline 105 & 0 & 0 & 3 & 4 \\
\hline 106 & 0 & 0 & 1 & 1 \\
\hline 108 & 3 & 4 & 4 & 5 \\
\hline 114 & 1 & 2 & 3 & 0 \\
\hline 118 & 5 & 4 & 5 & 5 \\
\hline 122 & 3 & 4 & 2 & 3 \\
\hline 126 & 5 & 5 & 5 & 5 \\
\hline 201 & 0 & 0 & 0 & 0 \\
\hline
\end{tabular}

6. Ignition results from the bench-scale testing correlated very well with corresponding data from the experiments with chairs made with the same fabrics and padding materials.

Table 6. Comparison of Ignition Propensties of Tested Cigarettes at Ful1 - and Bench-Scales

\begin{tabular}{rcr}
$\begin{array}{c}\text { Cigarette } \\
\text { Number }\end{array}$ & $\begin{array}{c}\text { Percent } \\
\text { Bench-Scale }\end{array}$ & $\begin{array}{r}\text { Ignitions } \\
\text { Full-S }\end{array}$ \\
\cline { 2 - 3 } 6 & 74 & 73 \\
129 & 13 & 23 \\
106 & 3 & 6 \\
114 & 6 & 14 \\
201 & 0 & 6
\end{tabular}

7. The physics of the ignition process is a function of both the cigarette and the substrate. Therefore, an accurate ignition propensity measurement apparatus must involve the two components.

Intrusive probes of the ignition process (e.g., thermocouples, heat flux gauges) perturb the delicately balanced system. The induced errors can be estimated if the probes are small and well-selected. With care, (nonintrusive) infrared imaging can be used to study the thermal profiles on non-igniting or igniting substrates. 
8. An approximate correlation exists between the cigarette coal area an ignition propensity. (Figure 3) Peak coal surface temperatures (and thu peak heat fluxes) did not vary sufficiently to demonstrate a correlation with ignition tendency for the cigarettes tested.

Oxygen depletion in the vicinity of the ignition site is important durin the ignition process, but was sufficiently similar for all cigarettes examined so as not to account for their relative ignition propensities.

9. It is possible to construct a complex computer model of the smoldering combustion of a cigarette and the response of an idealized substrate. With all its simplifications, this preliminary model is sufficiently realistic to (1) manifest the most important and most sensitive physical features of the ignition process (Figure 4) and (2) reproduce some of the cigarette characteristics that do and do not affec ignition propensity. Thus, the model could potentially be used to scree possible combinations of characteristics that offer increased fire safety. At present, however, the code for this preliminary model is ver slow and not user-friendly.

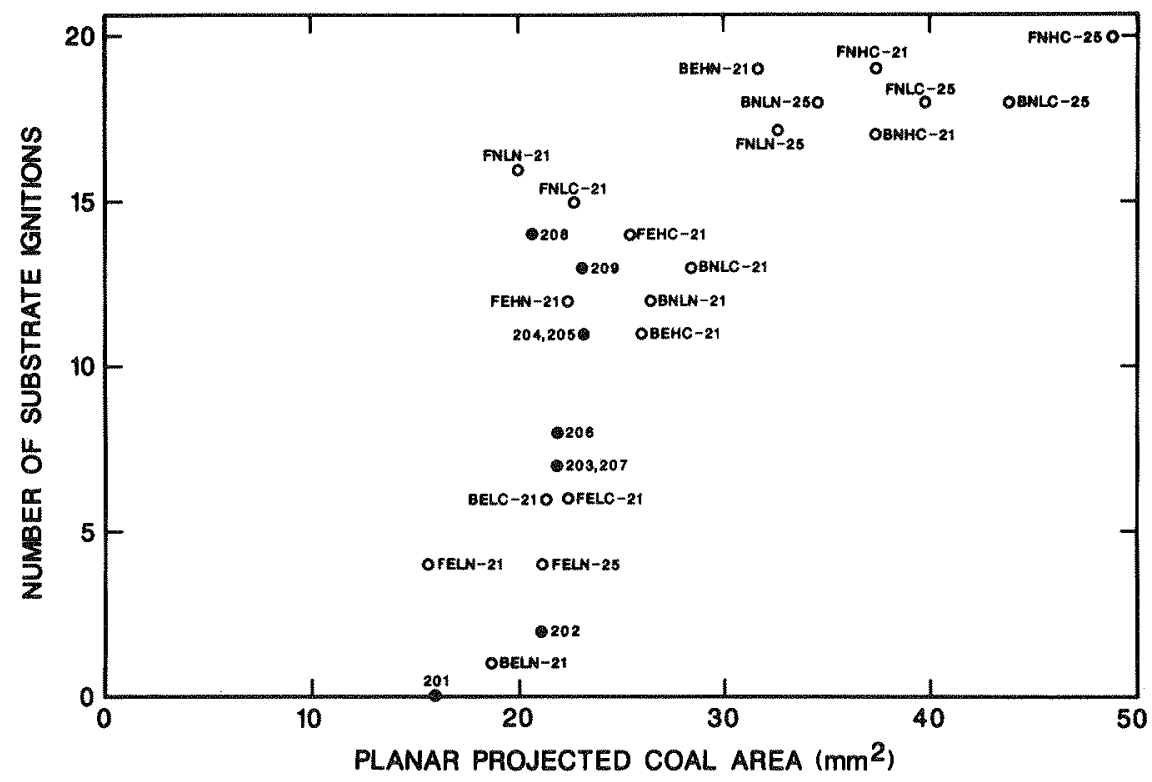

Figure 3. Number of Substrate Ignitions vs. Triangular Estimate of Planar Projected Coal Area. 


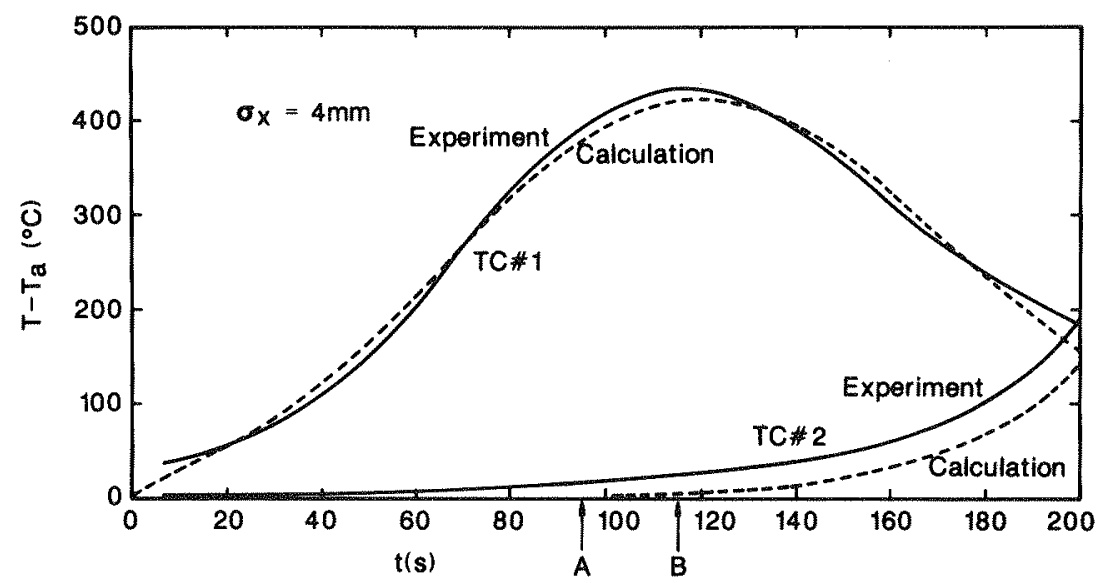

Figure 4. Calculated and Predicted Temperatures at Two Locations in the Substrate as the Smolder Wave from Cigarette 102 Passes Over Them.

10. The current, mini-mockup methods are valid for research measurements of the ignition propensity of cigarettes. However, their use in a standard test method of cigarette performance is compromised by the variability in the commercial fabrics and paddings used in the mockup.

Several alternative candidate test methods for measuring the cigarette ignition propensity of soft furnishings were evaluated; none was usable in its current state of development. Two promising approaches to cigarette testing are proposed. The first modifies the existing mockup procedure using specially-prepared, well-controlled fabrics and paddings. The second uses a non-reactive substrate at variable temperature to determine the minimum needed cigarette heat-loss rate for extinguishment. Al1 need further development before promulgation.

\section{CONCLUSION}

This research has identified a number of approaches whose successful pursuit would lead to less fire-prone cigarettes. Prototype computer modeling of the ignition process offers the potential to screen future cigarette designs. Alternatives are proposed for standard measurement of cigarette ignition propensity.

\section{ACKNOWLEDGEMENTS}

A large number of colleagues within the Center for Fire Research contributed to this project. This research was also greatly enhanced by discussions with the members of the Technical Study Group under the Cigarette Safety Act of 1984. Appreciation is expressed to Dr. Alexander Spears of Lorillard, Inc and to Roy Briggs of the Upholstered Furniture Action Council, who coordinated the production of the experimental cigarettes and the full-scale furniture, respectively. 


\section{REFERENCES}

This paper is a publication of the U.S. Government and is not subject to copyright.

1. Gann, R.G., Harris, Jr., R.H., Krasny, J.F., Levine, R.S., Mitler, H.E., and Ohlemiller, T.J., "The Effect of Cigarette Characteristics on the Ignition of Soft Furnishings," NBS Technical Note 1241, U.S. National Bureau of Standards, Gaithersburg, MD 20899, 1988.

2. Maxwel1, Jr., J.C., "The Maxwell Report: Revised 1985 Year-End Sales Estimates for the Cigarette Industry," Furman Selz Mager Dietz \& Birney, Inc., 1985 .

3. Hall, Jr. J.R., "Expected Changes in Fire Damages from Reducing Cigarette Ignition Propensity," Report No. 5, Technical Study Group, Cigarette Safety Act of 1984, 1987. (Copies of Technical Study Crou reports may be obtained from: Colin B. Church, U.S. Consumer Produc Safety Commission, 5401 Westbard Avenue, Washington, D.C. 20207.)

4. "Standard for the Flammability of Mattresses and Mattress Pads, " 16 Code of Federal Regulations, Part 1632, 1973.

5. "Cigarette Ignition Resistance of Components of Upholstered Furniture," NFPA 260A-1983, National Fire Codes, National Fire Protection Association, Quincy, Mass., published annually.

6. "Resistance of Mock-up Upholstered Furniture Material Assemblies to Ignition by Smoldering Cigarettes," NFPA 260B-1983, National Fire Codes, National Fire Protection Association, Quincy, Mass., publishe annually.

7. Ray, D., Consumer Product Safety Commission, private communication.

8. Krasny, J.F., "Cigarette Ignition of Soft Furnishings - A Literature Review With Commentary," NBSIR 87-3509, U.S. National Bureau of Standards, Gaithersburg, MD 20899, 1987.

9. Babrauskas, V., and Krasny, J.F., "Fire Behavior of Upholstered Furniture," NBS Monograph 173, U.S. National Bureau of Standards, Gaithersburg, MD, 1985.

10. Krasny, J.F. and Gann, R.G., "Relative Propensity of Selected Commercial Cigarettes to Ignite Soft Furnishings Mockups, " NBSIR 86 3421, U.S. National Bureau of Standards, Gaithersburg, MD 20899, 1986.

11. Damant, G.H., McCormack, J.A., and Claire, B., "Tests of Smoldering Ignition of Chairs and Reduced-Scale Mock-ups by Various Cigarettes, Report No. 7, Technical Study Group, Cigarette Safety Act of 1984 , 1987. 